\title{
Stakeholders' Attitudes about the Transplantations of the Mediterranean Seagrass Posidonia oceanica as a Habitat Restoration Measure after Anthropogenic Impacts: A Q Methodology Approach
}

\author{
Arturo Zenone ${ }^{1,+(\mathbb{D})}$, Carlo Pipitone ${ }^{1, *(\mathbb{D})}$, Giovanni D’Anna ${ }^{2}\left(\mathbb{D}\right.$, Barbara La Porta ${ }^{3}$, Tiziano Bacci ${ }^{3}$, Fabio Bertasi ${ }^{3}$ (D), \\ Claudia Bulleri ${ }^{4}$, Anna Cacciuni ${ }^{3}$, Sebastiano Calvo ${ }^{5}$, Stefano Conconi ${ }^{6}$, Maria Flavia Gravina ${ }^{7}$, \\ Cecilia Mancusi ${ }^{8}$, Alessandro Piazzi ${ }^{9}$, Monica Targusi ${ }^{3}$, Agostino Tomasello ${ }^{5}$ and Fabio Badalamenti ${ }^{1}$
}

check for updates

Citation: Zenone, A.; Pipitone, C.; D’Anna, G.; La Porta, B.; Bacci, T.; Bertasi, F.; Bulleri, C.; Cacciuni, A.; Calvo, S.; Conconi, S.; et al. Stakeholders' Attitudes about the Transplantations of the Mediterranean Seagrass Posidonia oceanica as a Habitat Restoration Measure after Anthropogenic Impacts: A Q Methodology Approach. Sustainability 2021, 13, 12216. https://doi.org/ $10.3390 /$ su132112216

Academic Editor: Richard H. Loyn

Received: 1 October 2021

Accepted: 29 October 2021

Published: 5 November 2021

Publisher's Note: MDPI stays neutral with regard to jurisdictional claims in published maps and institutional affiliations.

Copyright: (c) 2021 by the authors. Licensee MDPI, Basel, Switzerland. This article is an open access article distributed under the terms and conditions of the Creative Commons Attribution (CC BY) license (https:// creativecommons.org/licenses/by/ $4.0 /)$.
1 CNR-IAS, Lungomare Cristoforo Colombo 4521, 90149 Palermo, Italy; arturo.zenone@szn.it (A.Z.); fabio.badalamenti@cnr.it (F.B.)

2 CNR-IAS, Via Giovanni da Verrazzano 17, 91014 Castellammare del Golfo, Italy; giovanni.danna@cnr.it

3 ISPRA, Via Vitaliano Brancati 48, 00144 Roma, Italy; barbara.laporta@isprambiente.it (B.L.P.); tiziano.bacci@isprambiente.it (T.B.); fabio.bertasi@isprambiente.it (F.B.); anna.cacciuni@isprambiente.it (A.C.); monica.targusi@isprambiente.it (M.T.)

4 Autorità di Sistema Portuale del Mar Tirreno Settentrionale, Piazzale Premuda 6/a, 57025 Piombino, Italy; c.bulleri@portialtotirreno.it

5 Dipartimento di Scienze della Terra e del Mare, Università di Palermo, Viale delle Scienze Ed. 16, 90128 Palermo, Italy; sebastiano.calvo@unipa.it (S.C.); agostino.tomasello@unipa.it (A.T.)

6 VESENDA, Via Fratelli Cuzio 42, 27100 Pavia, Italy; s.conconi@vesenda.com

7 Dipartimento di Biologia, Università di Roma "Tor Vergata", Via della Ricerca Scientifica s.n.c., 00133 Roma, Italy; maria.flavia.gravina@uniroma2.it

8 ARPAT, Via Marradi 114, 57126 Livorno, Italy; c.mancusi@arpat.toscana.it

9 SETIN srl, Via Guido d'Arezzo 16, 00198 Roma, Italy; alessandro.piazzi@setinsrl.eu

* Correspondence: carlo.pipitone@cnr.it

† Current Address: Stazione Zoologica Anton Dohrn, Lungomare Cristoforo Colombo 4521, 90149 Palermo, Italy.

Abstract: Anthropogenic impacts on Posidonia oceanica meadows have led to a decline of this ecosystem throughout the Mediterranean. Transplantations have often been prescribed as a compensation measure to mitigate the impacts caused by coastal maritime works. Here a Q methodology approach was used to investigate the stakeholders' attitudes in four case studies of P. oceanica transplants realized in Italian waters. Twenty-two respondents were asked to score 37 statements, and the resultant Q-sorting was analyzed via an inverse PCA using the KADE software. Four discourses, corresponding to the significant axes in the factorial analysis were identified: science and conservation (F1), oriented at a rigorous scientific approach; engineering and industry (F2), oriented at the economic development; environmentalism and participation (F3), oriented at the conservation of seagrass meadows; and transplantation-oriented (F4), oriented at the realization of transplants as compensation measures. The main conflicts and agreements between discourses are assessed and discussed, based on the analysis of the distinguishing statements that contributed to consensus or disagreement among discourses. The benefits of the $\mathrm{Q}$ methodology in the identification and mediation of conflicts in the four case studies are discussed, and its potential as a powerful aid in the development of a good environmental governance is acknowledged.

Keywords: compensation measures; stakeholders' perception; environmental impact; environmental governance; conflict resolution

\section{Introduction}

Coastal zones are characterized by highly diverse geomorphological features and climatic conditions that provide a wide variety of valuable habitats and ecosystem services 
and are among the most productive areas in the world [1]. Due to the frequent presence of human settlements, coasts are often subject to intense anthropogenic pressures that risk to transform coastal landscapes and lead to biodiversity loss, habitat destruction, coastal erosion as well as to conflicts among users [2]. The European Union provides legislative tools aimed at achieving a sustainable development and use of coastal and maritime resources in an attempt to balance environmental, economic, social, cultural, and recreational objectives [3]. Anyway, light and shade emerge from the EU legislation as regards the actions against the effects of the growing human pressures on marine ecosystems [4].

Seagrasses are among the most valuable ecosystems in the shallow waters of all oceans [5] and are particularly threatened by human impacts [6,7]. In recent years, an enormous effort has been put in place to counter the effects of such impacts. In addition to conservation programs, seagrass transplantation has been indicated as a possible measure to compensate for the destruction of this ecosystem caused by human activities along the coasts.

The Mediterranean endemic seagrass Posidonia oceanica (L.) Delile forms littoral meadows that are widely distributed from very shallow waters to about $40 \mathrm{~m}$ depth [8]. These meadows characterize vast coastal areas and play an important ecological role related to the high biological diversity supported [9], and to the ecosystem services provided, which include oxygen production, carbon sequestration, nutrient recycling, protection against coastal erosion and provision of fisheries resources [5,7,10,11].

"Posidonia beds" are listed as a priority natural habitat type of Community interest for conservation under the Habitat Directive (92/43/EEC) and have a dedicated action plan in the Barcelona Convention for the Protection of the Marine Environment and the Coastal Region of the Mediterranean, under the "Protocol concerning Specially Protected Areas and Biological Diversity in the Mediterranean". P. oceanica is also one of the four biological quality elements in accordance with the Water Framework Directive (2000/60/EC) requirements and a target for good environmental status monitoring in the Italian implementation program of the Marine Strategy Framework Directive (2008/56/EC). Despite the protected status, local and global stressors have led to a general decline of P. oceanica meadows [12,13], with an estimated 34\% regression in the last 50 years [7]. This trend should be reversed in compliance to the EU Biodiversity Strategy for 2030 (COM (2020) 380 final), which prescribes the restoration of degraded ecosystems and at least no further net regression in the short term.

Infrastructural coastal works such as, e.g., harbor constructions and extensions or pipeline deployments are among the many activities that may severely impact $P$. oceanica meadows. In the European Union, such works are subject to environmental impact assessment (EIA) or strategic environmental assessment (SEA) according to the Impact Assessment Directive (2014/52/EU), and to national laws that provide for compensation when maritime works are expected to damage the meadows. In particular, transplantations of $P$. oceanica shoots have been prescribed often in Italy as a suitable compensation measure [14], although their effectiveness is still debated [15].

The existence of economic activities that have an impact on an ecosystem of pivotal importance, raises important questions all the more so because seagrass restoration is a highly debated topic at European level [16]. The raised questions regard a number of related issues, such as the selection of the most appropriate transplantation technique and of suitable recipient sites, the availability of propagules, the importance of monitoring, the sharing of and access to collected data and the availability of the results about the effectiveness of the transplant. The issue of public engagement and awareness in environmental matters in Europe is regulated by Directive 2014/52/EU and by the Aarhus Convention and is a crucial element in the realization of good environmental governance and instrumental to the success of environment-related initiatives [17-19]. The benefits of stakeholder involvement in environmental decisions are multiple and include the possibility of preventing or resolving conflicts and of increasing the social acceptability of initiatives $[20,21]$. 
Public participation may also lead to an overall improvement of the whole process through the contribution of local knowledge. For these reasons, the governance process in environmental matters should always be appropriately set and should provide the framework for adequate involvement of all the parties directly and indirectly concerned.

The SEPOSSO (Supporting Environmental governance for the POSidonia oceanica Sustainable transplanting Operations) project investigated the governance structure in three $P$. oceanica transplants realized as compensation measures and in one experimental transplant along the Italian coast. Drawing from the project activities and tasks, the objective of this paper is to evaluate for the first time the views and attitudes of selected stakeholders about the objectives, characteristics, and results of $P$. oceanica transplantations, and the benefits or detriments originated. To fulfil this task, the $Q$ methodology, an exploratory semi-quantitative tool originally developed to investigate subjectivity in psychology studies [22] but later applied to many other fields of research including environmental conservation [23], was adopted. The $Q$ methodology allows to identify stakeholders' visions (or discourses) that develop around a topic, and the points of agreement or disagreement among them [24]. Despite the high level of subjectivity and the heterogeneity of approaches used in the presentation of results [25] the output of a Q-based study may allow the evaluation of environmental policies [26], assist in conflict resolution and lead to the realization of a good governance structure, paving the path to effective, shared and socially acceptable management actions [20].

\section{Materials and Methods}

\subsection{Case Studies Selection}

Four P. oceanica transplantation initiatives realized between 2004 and 2014 along the Italian coast-three in the Tyrrhenian Sea and one in the SW Ionian Sea-were selected as case studies to investigate the attitudes of the stakeholders directly involved in the initiatives. The Tyrrhenian transplantations were realized to compensate for damage caused to native P. oceanica meadows by infrastructural works, while the Ionian transplantation was an experimental initiative [27]. Table 1 lists the case studies and their main characteristics.

Table 1. Main details and characteristics of four Posidonia oceanica transplantation case studies along the Italian coast (WGS84 coordinates).

\begin{tabular}{lcclll}
\hline \multicolumn{1}{c}{ Locality } & $\begin{array}{c}\text { Date of } \\
\text { Transplantation }\end{array}$ & Coordinates & Surface & Motivation & Technique \\
\hline $\begin{array}{l}\text { Piombino (northern } \\
\text { Tyrrhenian Sea) }\end{array}$ & Jun 2014 & $\begin{array}{l}42.944295^{\circ} \mathrm{N} \\
10.612316^{\circ} \mathrm{E}\end{array}$ & $1360 \mathrm{~m}^{2}$ & $\begin{array}{l}\text { Dredging works in } \\
\text { the harbor }\end{array}$ & $\begin{array}{l}\text { Clod of seagrass } \\
\text { matte }\end{array}$ \\
\hline $\begin{array}{l}\text { Civitavecchia (central } \\
\text { Tyrrhenian Sea) }\end{array}$ & Aug 2004-Mar 2005 & $\begin{array}{l}42.034567^{\circ} \mathrm{N} \\
11.890633^{\circ} \mathrm{E}\end{array}$ & $10,000 \mathrm{~m}^{2}$ & $\begin{array}{l}\text { Dredging works in } \\
\text { the harbor }\end{array}$ & $\begin{array}{l}\text { Grids of concrete } \\
\text { and steel wire }\end{array}$ \\
\hline $\begin{array}{l}\text { Ischia (southern } \\
\text { Tyrhhenian Sea) }\end{array}$ & Nov 2008-Feb 2009 & $\begin{array}{l}40.746826^{\circ} \mathrm{N} \\
13.949514^{\circ} \mathrm{E}\end{array}$ & $1600 \mathrm{~m}^{2}$ & $\begin{array}{l}\text { Trench excavation } \\
\text { for pipeline } \\
\text { deployment }\end{array}$ & $\begin{array}{l}\text { Grids of concrete } \\
\text { and steel wire }\end{array}$ \\
\hline $\begin{array}{l}\text { Priolo (southwestern } \\
\text { Ionian Sea) }\end{array}$ & Jun-Nov 2014 & $\begin{array}{l}37.160970^{\circ} \mathrm{N} \\
15.220278^{\circ} \mathrm{E}\end{array}$ & $2500 \mathrm{~m}^{2}$ & $\begin{array}{l}\text { Experimental } \\
\text { transplant }\end{array}$ & $\begin{array}{l}\text { Bio-plastic support } \\
\text { modules }\end{array}$ \\
\hline
\end{tabular}

\subsection{Q Methodology}

A Q methodology approach was followed to investigate the attitudes of selected stakeholders about $P$. oceanica transplantations in the four case study localities. A standard approach consisting of five steps was followed [28,29]: (1) creation of a collection of statements, concourse; (2) extraction of a selected sub-set of statements, $Q$-set; (3) definition of the set of participants asked to score the statements, $P$-set; (4) rank-ordering of the statements and statistical analysis, $Q$-sorting; (5) interpretation of the discourses, i.e., the stakeholders' visions stemming out from interviews to stakeholders, critical reading of the statements, case studies' EIA reports and from the academic and grey literature. A final 
Q-set of 37 statements was extracted after a process of refinement based on the elimination of duplicate or unclear statements, and considered broad and diverse enough to cover the full spectrum of policy, science, and management aspects of the investigated topic (Table 2).

Table 2. List of the 37 selected statements included in the Q-set.

\begin{tabular}{|c|c|}
\hline No. & Statement \\
\hline 1 & A transplantation technique that is considered the most appropriate to the transplant site should be adopted \\
\hline 2 & The information that leads to choose the transplantation as a compensation measure should be clear and easily accessible \\
\hline 3 & A mismatch between administrative and technical terminology exists in the EIA prescriptions that impose the transplantation \\
\hline 4 & The choice of the transplantation technique should be based on an accurate environmental study of the transplant site \\
\hline 5 & $\begin{array}{l}\text { A marine protected area should be established in addition to the transplantation to assure the full restoration of ecosystem functions } \\
\text { lost due the infrastructural works }\end{array}$ \\
\hline 6 & P. oceanica transplantations are not a priority for the country \\
\hline 7 & $\begin{array}{l}\text { Among compensation measures, public meetings should be held to awaken the public opinion to conservation and environmental } \\
\text { issues }\end{array}$ \\
\hline 8 & The choice of the transplantation technique should be based on the most recent scientific knowledge \\
\hline 9 & $\begin{array}{l}\text { Social acceptance of the infrastructural works and of the compensation measures is a prerequisite to a good governance of the } \\
\text { transplantation initiative }\end{array}$ \\
\hline 10 & P. oceanica should be protected, not transplanted \\
\hline 11 & P. oceanica is a waste \\
\hline 12 & A transplantation initiative should involve local skills, abilities, and cultural heritage \\
\hline 13 & Pilot transplantations should be realized in the identified transplant site before the start of the infrastructural works \\
\hline 14 & Monitoring outputs should be made public in an easily accessible and understandable format \\
\hline 15 & A transplantation should produce easily accessible new knowledge and data \\
\hline 16 & Maritime infrastructural works are necessary to the economic growth of the country \\
\hline 17 & Priority habitats as defined by the EC Habitat Directive should never be impacted by infrastructural works \\
\hline 18 & The environmental effects of a transplantation should be made public \\
\hline 19 & EIA prescriptions should be drawn up by a multidisciplinary expert team \\
\hline 20 & Transplantations should be bound to the stakeholders' acceptance \\
\hline 21 & The main aim of EIA should be ecosystem protection \\
\hline 22 & Transplantations should always be realized by an experienced team \\
\hline 23 & A transplant alone cannot warrant all the ecosystem functions originally provided by the damaged seagrass meadow \\
\hline 24 & The restoration of lost ecosystem functions is more important than economic convenience in the choice of transplantation technique \\
\hline 25 & Tenders for the allotment of a transplantation initiative should not be based solely on a lowest-bid contract \\
\hline 26 & Economic development should not be subject to extreme conservation logics \\
\hline 27 & $\begin{array}{l}\text { The citizens should be fully informed about objectives, techniques, and costs of a transplantation initiative during its early stages, not } \\
\text { merely after its completion }\end{array}$ \\
\hline 28 & Links and synergies among the stakeholders directly involved in a transplantation initiative are insufficient \\
\hline 29 & Transplantation initiatives should be fully regulated \\
\hline 30 & The governance of a transplantation initiative should be adapted to the local socio-economic context \\
\hline 31 & Transplant monitoring should be carried out by an external scientific team rather than by the one who realized the transplant \\
\hline 32 & The creation of centers for the collection and storage of beach-cast rhizomes and seeds of $P$. oceanica is a priority \\
\hline 33 & Transplant monitoring should be a long-term activity \\
\hline 34 & The data collected before and after realized transplantations are not adequately organized, shared, and exploited \\
\hline 35 & The loss of $P$. oceanica meadows is an inevitable cost of modernization \\
\hline 36 & To avoid tensions, transplantation initiatives should be based on the agreement of all (national, regional, local) political actors \\
\hline 37 & All steps of a transplantation initiative should be traceable, clear, and accessible \\
\hline
\end{tabular}




\subsection{P-Set}

Twenty-two participants directly involved or interested in the matter of P. oceanica transplantations as a compensation measure were selected to build the $P$-set. They were practitioners or academics belonging to public research, academia, industries involved in maritime works, consulting firms, the environmentalist sector and to local and national government authorities, that is the main (even though not the only) stakeholder categories involved. Their selection was made according to a strategic-i.e., not random-principle to ensure the coverage of a wide range of viewpoints on the investigated matter and to satisfy criteria of quality, competence, and diversity of opinions [24,29].

\subsection{Q-Sorting}

All statements were numbered randomly. Since the $P$-set members were distributed in different and far-away localities it was not feasible to gather all of them and proceed with a face-to-face session for the Q-sorting. Each participant received the statements along with an empty triangular grid designed to enter each statement number (Figure 1) and was requested to (i) read all statements; (ii) group them in three clusters according to the generic level of agreement to that statement (positive, negative, neutral); (iii) assign a score to each statement (Q-SV: $\mathrm{Q}$ statement value) that ranged from -4 (full disagreement) to +4 (full agreement), including a neutral $(=0)$ score, and input each statement number in the triangular grid according to its own score; (iv) double-check the scoring to make sure of its correctness. Then all respondents were individually interviewed on the phone or in presence about the motivation of their responses, until all inconsistencies and tricky points were sorted out. In some cases, a partial re-evaluation of statements in the grid was required. This final interview was also essential to obtain information useful to the interpretation of the results during the successive discourse analysis. The whole Q-sorting process lasted from June to August 2019.

\begin{tabular}{|c|c|c|c|c|c|c|c|c|}
\hline \multicolumn{7}{|c|}{ Disagreement } & \multicolumn{2}{|c|}{ Agreement } \\
\hline-4 & -3 & -2 & -1 & 0 & +1 & +2 & +3 & +4 \\
\hline & & & & & & & & \\
\hline & & & & & & & & \\
\hline & & & & & & & & \\
\hline & & & & & & & & \\
\hline & & & & & & & & \\
\hline & & & & & & & & \\
\hline & & & & & & & & \\
\hline
\end{tabular}

Figure 1. Triangular grid used for the Q-sorting procedure. 


\subsection{Discourse Analysis}

Q-sort data, i.e., the distribution of Q-SV scores given to statements by $P$-set respondents, were analyzed with the KADE software (KADE (Ken-Q Analysis Desktop Edition v.1.0.6 is a free software available at https:/ / shawnbanasick.github.io/ken-q-analysis/, last access on 15 September 2021) [30]. KADE analysis started with the correlation of each participant's Q-sort with those of all other participants. A principal component analysis was performed on the resulting correlation matrix to produce statistically significant factors that suggested similar perspectives on the matter of study. Four meaningful factors were then selected based on an eigenvalue $>1$ and on the percentage of explained variance. A Varimax rotation applied to the selected factors as suggested by Zabala [31], produced a table with factor loadings by participants. Participants' loadings were auto-flagged in the factors with a $95 \%$ confidence level. The subsequent steps produced a series of tables with the Z-score ranking of each statement and the distinguishing statements in each factor. These tables were used by the software to build a series of reconfigured Q-sorts (one for each factor) based on the composite and weighted Z-scores from all the participants who define a particular factor, called composite Q-sorts (Table S1).

\section{Results}

The principal component analysis conducted on the 22 Q-sorts highlighted four significant factors that explain $67 \%$ of the total variance (Table 3 ).

Table 3. Characteristics of the four significant factors (discourses) selected from the analysis. s.e.: standard error.

\begin{tabular}{ccccccc}
\hline Factors & $\begin{array}{c}\text { No. of } \\
\text { Defining } \\
\text { Variables }\end{array}$ & Eigenvalues & $\begin{array}{c}\text { \% } \\
\text { Explained } \\
\text { Variance }\end{array}$ & $\begin{array}{c}\text { Average } \\
\text { Reliability } \\
\text { Coefficient }\end{array}$ & $\begin{array}{c}\text { Composite } \\
\text { Reliability }\end{array}$ & $\begin{array}{c}\text { s.e. of } \\
\text { Factors' } \\
\text { Z-Scores }\end{array}$ \\
\hline F 1 & 7 & 7.230 & 33 & 0.8 & 0.966 & 0.184 \\
\hline F 2 & 6 & 4.095 & 19 & 0.8 & 0.960 & 0.200 \\
\hline F 3 & 4 & 1.907 & 9 & 0.8 & 0.941 & 0.243 \\
\hline F 4 & 5 & 1.424 & 6 & 0.8 & 0.952 & 0.219 \\
\hline
\end{tabular}

The list of ranked statements in each factor is shown in Table S2. Statements 21 (the main aim of EIA should be ecosystem protection) and 11 (P. oceanica is a waste) ranked 1st and 37th respectively in Factor 1. Due to their ranking, they concentrate maximum agreement and maximum disagreement from the respondents associated to that factor, respectively. The statements that ranked first and last in the other significant factors were: 8 (the choice of the transplantation technique should be based on the most recent scientific knowledge) and 17 (priority habitats as defined by the Habitat Directive should never be impacted by infrastructural works) in Factor 2; 10 (P. oceanica should be protected, not transplanted) and 11 (P. oceanica is a waste) in Factor 3; 37 (all steps of a transplantation initiative should be traceable, clear, and accessible) and 11 (P. oceanica is a waste) in Factor 4. Statement 11 ranked the lowest in three factors and relatively low in Factor 2, which indicates a very strong disagreement by most respondents. 
Discourses, which represent the attitudes of $P$-set respondents about the issue of $P$. oceanica transplantations as a compensation tool, correspond to the significant factors that emerged from the principal component analysis. Their characterization and description were based on the composite Q-sorts (Table S1), which allowed us to identify the distinguishing statements of each factor. The four discourses were entitled considering the statements' content and the result of the interviews made to respondents, as follows:

F1: Science and conservation discourse;

F2: Engineering and industry discourse;

F3: Environmentalism and participation discourse;

F4: Transplantation-oriented discourse.

\subsection{Characterization and Description of Discourses}

\subsubsection{F1: Science and Conservation Discourse}

This discourse expresses a vision strongly inspired by the importance of nature conservation and by the most rigorous, science-based approach to transplantations. The protection of P. oceanica meadows as well as other priority habitats is considered a top priority that should be taken into consideration during the planning of infrastructural works at sea. The demand for seagrass conservation is expressed by agreement with Statement 10 and especially Statement 21, and by disagreement with Statement 26. A high attention is posed on the pre-requisites that are expected to assure a highly successful transplantation, such as the choice of the methodology, the necessity of preliminary studies, and the adoption of pilot transplant experiments. Emphasis is posed in long-term monitoring of transplants to be sure that they are effective in the long run. Agreement with Statements 13 and 33 testifies the confidence placed in a rigorous scientific approach that ensures effective transplantation techniques through the use of pilot experiments and subsequent long-term monitoring. Neutral or negative opinion was expressed instead for Statements 28, 7, 9 and 18, which correspond to different levels of public engagement in the transplantation initiatives. Overall, there is an attention towards sustainable development, as suggested by the disagreement against statements that emphasize the importance of modernization and industrialization (Statements 26, and 35).

\subsubsection{F2: Engineering and Industry Discourse}

This discourse expresses a vision oriented at granting the economic development of the country (Statement 16) even at the expense of the ecosystem (Statements 17, 21, 24). The importance of sound scientific advice that assures effective transplantations is acknowledged (Statement 8), although monitoring carried out by the actual transplant realizer is preferred over one carried out by an external, independent team (Statement 31). The necessity to avoid non-optimal choices dictated by the mere search for profit is acknowledged (Statement 25). The influence of extreme conservation logics (Statement 26) and an interdisciplinary team that draws EIA prescriptions (Statement 19) are both considered an impediment. An ambivalent attitude is expressed as regards citizens' participation: while social acceptance of infrastructural works and of transplantations is considered an important pre-requisite (Statement 9), as well as the adaptation of governance to the local socio-economic context and the preliminary agreement of political forces (Statements 30, and 36), workshops organized to enhance the awareness of citizens towards conservation issues (Statement 7) are not considered necessary.

\subsubsection{F3: Environmentalism and Participation Discourse}

This discourse is strongly oriented at avoiding any damage to P. oceanica at all costs. This translates in a position that stands against transplantations (Statement 10) no matter how sound the scientific background is and how clearly the information about the transplantation is delivered (Statements 1, 22, and 2). In addition, different compensation measures (such as the establishment of marine protected areas) are favored over transplants in order to obtain a full recovery of ecosystem functions (Statement 5). Public information, 
social acceptance of infrastructural works and compensation measures and more generally the involvement of citizens are considered important (Statements 9, and 20), and a major role is acknowledged to long-term monitoring activities and to the relevant data produced (Statements 15, and 33). Overall, this discourse is basically against any sort of impact on seagrass meadows, irrespective of the compensation measures proposed and of the diffusion of information about the transplantation.

\subsubsection{F4: Transplantation-Oriented Discourse}

The last discourse is oriented towards the realization of maritime works also even if they impact sensitive habitats (Statement 17), and subsequent transplantations should be realized even in the absence of a general agreement from all the political bodies involved locally and nationally (Statement 36). Maritime infrastructures are not considered a necessary step towards the economic growth of the country though (Statement 16). Governance mechanisms are deemed faulty, and a more effective administration is considered an important issue (Statement 3). Transparency of the whole transplantation process and access of citizens to the data (Statement 37), and the importance of data quality and accessibility (Statements 15, and 34) are acknowledged.

\subsection{Differentiation among Discourses}

Four statements (Table 4; see also Table S1) are consensus statements and should be interpreted as points of agreement among the discourses: 14 (monitoring outputs should be made public in an easily accessible and understandable format: positive agreement), 27 (the citizens should be fully informed about objectives, techniques, and costs of a transplantation initiative during its early stages, not merely after its completion: neutral agreement), 29 (transplantation initiatives should be fully regulated: negative agreement), and 35 (the loss of P. oceanica meadows is an inevitable costs of modernization: negative agreement). While these statements do not help in the differentiation among discourses, they are potential starting points to build consensus among stakeholders around the issue of P. oceanica transplantations.

Table 4. List of statements that obtained consensus at the Q sorting.

\begin{tabular}{ccccccccc}
\hline & \multicolumn{2}{c}{ F1 } & \multicolumn{2}{c}{ F2 } & \multicolumn{2}{c}{ F3 } & \multicolumn{2}{c}{ F4 } \\
\hline Statement & Q-SV & Z-Score & Q-SV & Z-Score & Q-SV & Z-Score & Q-SV & Z-Score \\
\hline $14^{* *}$ & 1 & 0.36 & 1 & 0.499 & 1 & 0.502 & 2 & 1.02 \\
\hline $27^{*}$ & 0 & -0.222 & 0 & -0.187 & 0 & 0.372 & 0 & 0.318 \\
\hline $29^{* *}$ & 0 & -0.2 & -2 & -0.89 & -1 & -0.74 & -1 & -0.23 \\
\hline $35^{* *}$ & -3 & -1.4 & -2 & -0.83 & -2 & -1.01 & -3 & -1.56 \\
\hline
\end{tabular}

Q-SV: statement value given by the $P$-set respondents. ${ }^{*}=$ non-significant at $p<0.05$; ${ }^{* *}=$ non-significant at $p<0.01$.

The relation among discourses is visually represented in Figure 2, where the physical distance of symbols on each line of the plot indicates the level of agreement or disagreement among discourses around each statement (closer distance = higher agreement). The four statements at the bottom are the consensus statements already described. The top statements represent the most distinctive ones, i.e., those showing maximum divergence among discourses. Statements 16 and 26 regard the necessity of infrastructural maritime works and the subjugation of economic development to conservation logics. As expected, the F2 discourse stays at one end while F1 and F3 stay at the other end. Statements 17 and 21 regard nature conservation and ecosystem protection, and also in this case discourses F1 and F2 stay at the opposite ends of the Z-score range. Statement 10 expresses a very drastic position that is strongly agreed upon only by discourse F3. 


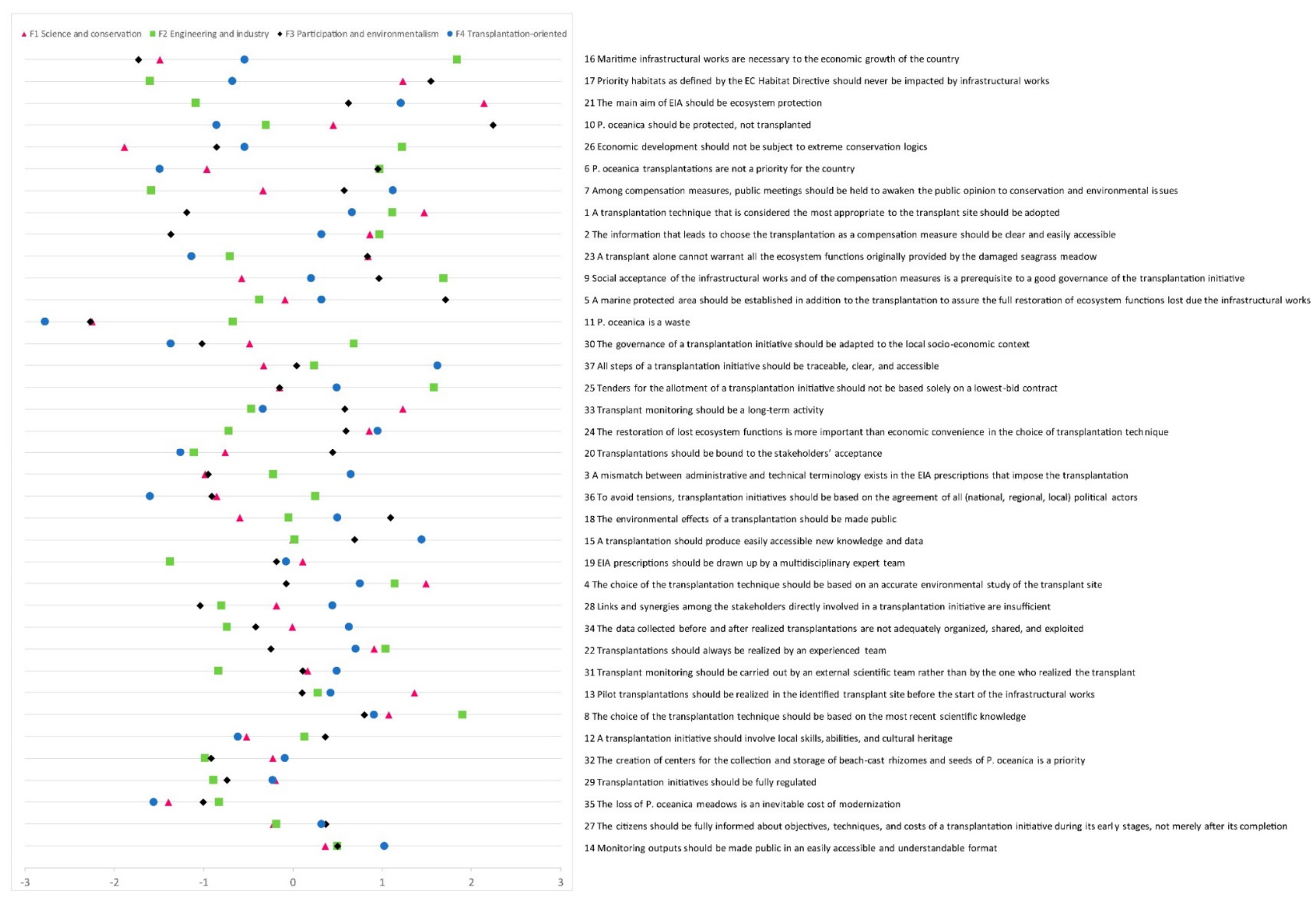

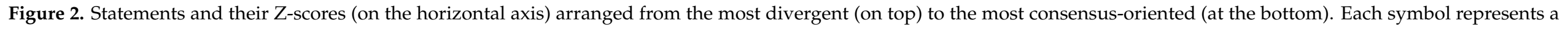
different discourse (see legend). 


\section{Discussion}

Identifying the discourses developed by selected stakeholders around matters of common interest is a good way to find common grounds, mediate conflicts and proceed towards shared and successful management of complex processes [32]. The knowledge of discourses made about the environment may definitely help to understand if environmental policies are acceptable by specific societal sectors as well as by the wider public $[24,26,33]$. The $Q$ methodology provides an excellent help in this direction. For this reason, it has been applied often to analyze environmental governance in the field of nature conservation [21,34-36], fisheries management $[20,37]$, ecosystem services $[28,29,38]$ and sustainability $[33,39,40]$.

This study has investigated for the first time the views and attitudes of selected stakeholders about $P$. oceanica transplantations prescribed to compensate the impact of marine infrastructural works on P. oceanica meadows and also about an experimental transplant in an area affected by severe industrial pollution. The application of a $Q$ methodology approach allowed us to identify four discourses that represent the visions of stakeholders directly involved in P. oceanica transplantations in Italy. The graphical representation of the relationships among discourses (Figure 2) gave us clues to identify the conflicts and the points of agreement between them.

Consensus statements helped to identify shared attitudes. These regard societal, economic, and scientific issues around which there is common agreement, disagreement or even neutrality of opinion. More critical, and more important is the identification of conflicts among visions, which require an effort to be solved [17]. The results of this study illustrate the relationships among discourses and shows how each vision affects the others, as pictured in Figure 3. The engineering and industry discourse (F2) supports a vision that emphasizes the importance and necessity of industrial and economic development, even when it implies a strong impact on the ecosystem. This discourse refuses the constraints imposed by an environmentalist logic but acknowledges the importance of appropriate and competent scientific advice in the realization of the transplants and considers the social acceptance of maritime works and of compensatory transplants a mainstay. The F2 discourse shares some common ground with the Transplantation-oriented discourse (F4), which strongly supports transplantations as a compensation measure and at the same time expresses the need of a more effective involvement of citizens in terms of transparency of the procedures and accessibility to data and knowledge.

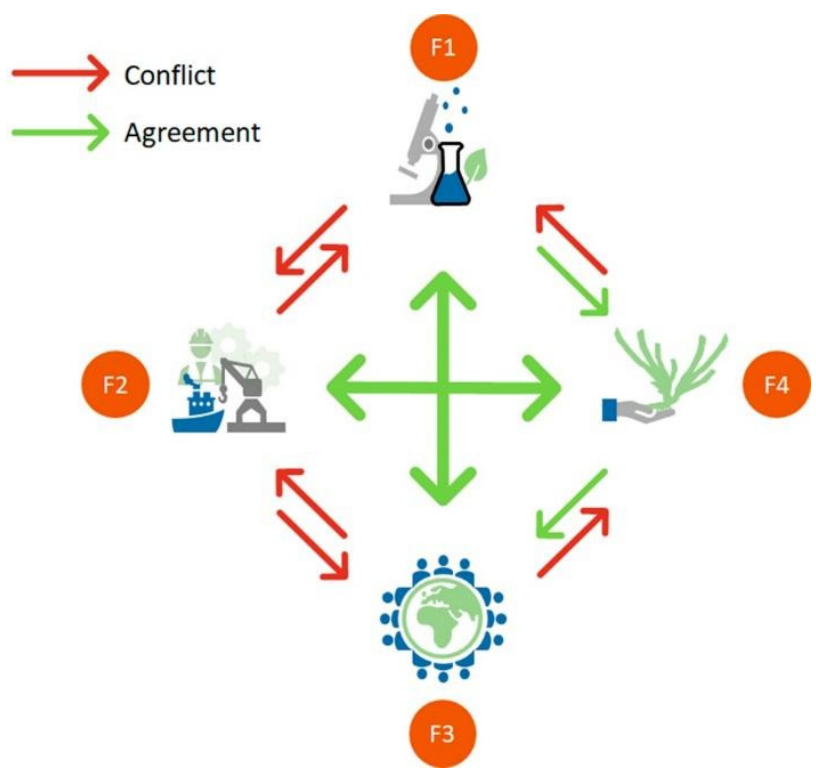

Figure 3. Relationships among discourses as highlighted by the discourse analysis. F1: science and conservation discourse; F2: engineering and industry discourse; F3: environmentalism and participation discourse; F4: transplantation-oriented discourse. 
The science and conservation (F1) and the environmentalism and participation discourses (F3) share a common attitude and tend to set against the previous two. They share a common vision oriented at the protection of the environment, the recovery of lost ecosystem services and the full involvement of local populations, with some peculiar statements such as the emphasis on the role expected by the EIA commission in the protection of the ecosystem (F1), and the firm belief that seagrass meadows should never be impacted, no matter what the compensation measures might bring in terms of habitat recovery (F3).

In some cases, the points of disagreement that we have highlighted could be smoothed out (green arrows in Figure 3). This would pave the way to a more effective governance of transplantation initiatives with positive spin-off on all the parties involved. For example, scientific expertise is necessary to the realization of transplants, hence F1 and F4 are expected to be synergistic on this matter since both of them aim at transplants that are stable in the long run and effective in the compensation of the damage produced by infrastructural works. Another common ground exists between F4 and F3, based on the agreement about the importance of an effective governance that assures fuller involvement of citizens and easy access to data collected and knowledge gained during the transplantation.

Seagrass meadows provide numerous ecosystem services, however, they are widely threatened by anthropogenic pressures that have led to their decline at a Mediterranean [7] and global scale [41]. The management of P. oceanica in the western Mediterranean has recently been perceived as inadequate by stakeholders [38], hence an adaptive governance of all initiatives that regard this peculiar ecosystem is needed. This is even more important when it comes to the conflicts existing between economic interests (e.g., infrastructural maritime works) and conservation demands. The $\mathrm{Q}$ methodology approach adopted in this paper has highlighted consensus points and, more importantly, conflicts that need to be addressed and resolved in the framework of a suitable governance structure. Our study provides a potential basis for implementing a sustainable governance and assuring high social acceptability in any future initiative concerning P. oceanica transplantations.

Supplementary Materials: The following are available online at https:/ /www.mdpi.com/article/10 $.3390 /$ su132112216/s1, Table S1: list of the 37 selected statements with the composite Q-sorts and their significance level; Table S2: Z-score of statements and associated ranks.

Author Contributions: Conceptualization: A.Z., F.B. (Fabio Badalamenti); data curation, formal analysis: A.Z.; investigation: F.B. (Fabio Badalamenti), G.D., C.P., A.Z.; project administration: T.B., B.L.P.; original draft preparation: A.Z., G.D.; interviews, data validation: F.B. (Fabio Badalamenti), A.Z.; supervision, editing, final review: C.P.; review and contribution with ideas and discussions: all authors. All authors have read and agreed to the published version of the manuscript.

Funding: The meetings held for the completion of this study were funded by the SEPOSSO project (Supporting Environmental governance for the POSidonia oceanica Sustainable transplanting Operations) (LIFE16 GIE/IT /000761). Project Marine Hazard (PON03PE_00203_1) provided financial support to the publication.

Institutional Review Board Statement: Not applicable.

Informed Consent Statement: Not applicable.

Data Availability Statement: All data and materials are available upon request.

Acknowledgments: This study was conducted in the frame of the SEPOSSO project (Supporting Environmental governance for the POSidonia oceanica Sustainable transplanting Operations) (LIFE16 GIE/IT/000761). The authors thank heartily all $P$-set participants, without whom this study could have not been carried out, and Evelyn Scicchigno, Maria Puleo and Giuseppe Di Stefano for the administrative and technical support.

Conflicts of Interest: The authors declare no conflict of interest. 


\section{References}

1. Arkema, K.K.; Verutes, G.M.; Wood, S.A.; Clarke-Samuels, C.; Rosado, S.; Canto, M.; Rosenthal, A.; Ruckelshaus, M.; Guannel, G.; Toft, J.; et al. Embedding ecosystem services in coastal planning leads to better outcomes for people and nature. Proc. Natl. Acad. Sci. USA 2015, 112, 7390-7395. [CrossRef]

2. Bulleri, F.; Chapman, M.G. The introduction of coastal infrastructure as a driver of change in marine environments. J. Appl. Ecol. 2010, 47, 26-35. [CrossRef]

3. Khakzad, S.; Pieters, M.; Van Balen, K. Coastal cultural heritage: A resource to be included in integrated coastal zone management. Ocean Coast. Manag. 2015, 118, 110-128. [CrossRef]

4. $\quad$ Fraschetti, S.; Pipitone, C.; Mazaris, A.D.; Rilov, G.; Badalamenti, F.; Bevilacqua, S.; Claudet, J.; Caric, H.; Dahl, K.; D'Anna, G.; et al. Light and shade in marine conservation across European and contiguous seas. Front. Mar. Sci. 2018, 5, 420. [CrossRef]

5. Vassallo, P.; Paoli, C.; Rovere, A.; Montefalcone, M.; Morri, C.; Bianchi, C.N. The value of the seagrass Posidonia oceanica: A natural capital assessment. Mar. Pollut. Bull. 2013, 75, 157-167. [CrossRef]

6. Waycott, M.; Duarte, C.M.; Carruthers, T.J.B.; Orth, R.J.; Dennison, W.C.; Olyarnik, S.; Calladine, A.; Fourqurean, J.W.; Heck, K.L.; Hughes, A.R.; et al. Accelerating loss of seagrasses across the globe threatens coastal ecosystems. Proc. Natl. Acad. Sci. USA 2009, 106, 12377-12381. [CrossRef]

7. Telesca, L.; Belluscio, A.; Criscoli, A.; Ardizzone, G.; Apostolaki, E.T.; Fraschetti, S.; Gristina, M.; Knittweis, L.; Martin, C.S.; Pergent, G.; et al. Seagrass meadows (Posidonia oceanica) distribution and trajectories of change. Sci. Rep. 2015, 5, 12505. [CrossRef]

8. Boudouresque, C.-F.; Charbonnel, E.; Meinesz, A.; Pergent, G.; Pergent-Martini, C.; Cadiou, G.; Bertrandy, M.C.; Foret, P.; Ragazzi, M.; Rico-Raimondino, V. A Monitoring Network based on the seagrass Posidonia oceanica in the Northwestern Mediterranean sea. Biol. Mar. Medit. 2000, 7, 328-331.

9. Duarte, C.M. Marine biodiversity and ecosystem services: An elusive link. J. Exp. Mar. Biol. Ecol. 2000, 250, 117-131. [CrossRef]

10. Campagne, C.S.; Salles, J.-M.; Boissery, P.; Deter, J. The seagrass Posidonia oceanica: Ecosystem services identification and economic evaluation of goods and benefits. Mar. Pollut. Bull. 2015, 97, 391-400. [CrossRef]

11. Zunino, S.; Melaku Canu, D.; Marangon, F.; Troiano, S. Cultural Ecosystem Services Provided by Coralligenous Assemblages and Posidonia oceanica in the Italian Seas. Front. Mar. Sci. 2020, 6, 823. [CrossRef]

12. Boudouresque, C.-F.; Bernard, G.; Pergent, G.; Shili, A.; Verlaque, M. Regression of Mediterranean seagrasses caused by natural processes and anthropogenic disturbances and stress: A critical review. Bot. Mar. 2009, 52, 395-418. [CrossRef]

13. Abadie, A.; Pace, M.; Gobert, S.; Borg, J.A. Seascape ecology in Posidonia oceanica seagrass meadows: Linking structure and ecological processes for management. Ecol. Indic. 2018, 87, 1-13. [CrossRef]

14. Bacci, T.; Scardi, M.; Calvo, S.; Tomasello, A.; Valiante, L.M.; Di Nuzzo, F.; Raimondi, V.; Assenzo, M.; Mancusi, C.; Piazzi, L.; et al. The life S.E.POS.S.O. monitoring of the Posidonia oceanica (L.) Delile transplantations in Italy. Biol. Mar. Mediterr. 2019, 26, 132-135.

15. Boudouresque, C.-F.; Blanfuné, A.; Pergent, G.; Thibaut, T. Restoration of Seagrass Meadows in the Mediterranean Sea: A Critical Review of Effectiveness and Ethical Issues. Water 2021, 13, 1034. [CrossRef]

16. Cunha, A.H.; Marbá, N.N.; van Katwijk, M.M.; Pickerell, C.; Henriques, M.; Bernard, G.; Ferreira, M.A.; Garcia, S.; Garmendia, J.M.; Manent, P. Changing Paradigms in Seagrass Restoration. Restor. Ecol. 2012, 20, 427-430. [CrossRef]

17. Redpath, S.M.; Young, J.; Evely, A.; Adams, W.M.; Sutherland, W.J.; Whitehouse, A.; Amar, A.; Lambert, R.A.; Linnell, J.D.C.; Watt, A.; et al. Understanding and managing conservation conflicts. Trends Ecol. Evol. 2013, 28, 100-109. [CrossRef]

18. Madden, F.; McQuinn, B. Conservation's blind spot: The case for conflict transformation in wildlife conservation. Biol. Conserv. 2014, 178, 97-106. [CrossRef]

19. Bennett, N.J. Using perceptions as evidence to improve conservation and environmental management. Conserv. Biol. 2016, 30, 582-592. [CrossRef]

20. Gall, S.C.; Rodwell, L.D. Evaluating the social acceptability of Marine Protected Areas. Mar. Policy 2016, 65, 30-38. [CrossRef]

21. Hagan, K.; Williams, S. Oceans of discourses: Utilizing Q methodology for analyzing perceptions on marine biodiversity conservation in the Kogelberg biosphere reserve, South Africa. Front. Mar. Sci. 2016, 3, 188. [CrossRef]

22. Stephenson, W. Correlating persons instead of tests. J. Pers. 1935, 4, 17-24. [CrossRef]

23. Bennett, N.J.; Di Franco, A.; Calò, A.; Nethery, E.; Niccolini, F.; Milazzo, M.; Guidetti, P.; Satterfield, T.; Dearden, P.; Watts, S.; et al. Local support for conservation is associated with perceptions of good governance, social impacts, and ecological effectiveness. Mar. Ecol. Prog. Ser. 2014, 3, 337-340. [CrossRef]

24. Webler, T.; Danielson, S.; Tuler, S. Using Q Method to Reveal Social Perspectives in Environmental Research; Social and Environmental Research Institute: Greenfield, MA, USA, 2009.

25. Sneegas, G.; Beckner, S.; Brannstrom, C.; Jepson, W.; Lee, K.; Seghezzo, L. Using Q-methodology in environmental sustainability research: A bibliometric analysis and systematic review. Ecol. Econ. 2021, 180, 106864. [CrossRef]

26. Lovett, J.C.; Takshe, A.A.; Kamkar, F. Evaluation of Environmental Policy with Q Methodology. In Oxford Research Encyclopedia of Environmental Science. Available online: https:/ / oxfordre.com/environmentalscience/view/10.1093/acrefore/9780199389414.00 1.0001/acrefore-9780199389414-e-713 (accessed on 7 September 2021).

27. Tomasello, A.; Pirrotta, M.; Calvo, S. Construction underwater landscape by using Posidonia oceanica transplanting combined with innovative artificial reefs. In Proceedings of the 6th Mediterranean Symposium on Marine Vegetation, Antalya, Turkey, 14-15 January 2019; Langar, H., Ouerghi, A., Eds.; SPA/RAC: Tunis, Tunisia, 2019; pp. 92-97. 
28. Hermelingmeier, V.; Nicholas, K.A. Identifying Five Different Perspectives on the Ecosystem Services Concept Using Q Methodology. Ecol. Econ. 2017, 136, 255-265. [CrossRef]

29. Sy, M.M.; Rey-Valette, H.; Simier, M.; Pasqualini, V.; Figuières, C.; De Wit, R. Identifying Consensus on Coastal Lagoons Ecosystem Services and Conservation Priorities for an Effective Decision Making: A Q Approach. Ecol. Econ. 2018, 154, 1-13. [CrossRef]

30. Banasick, S. KADE: A desktop application for Q methodology. J. Open Source Softw. 2019, 4, 1360. [CrossRef]

31. Zabala, A. qmethod: A Package to Explore Human Perspectives Using Q Methodology. R J. 2014, 6, 163-173. [CrossRef]

32. Zabala, A.; Sandbrook, C.; Mukherjee, N. When and how to use Q methodology to understand perspectives in conservation research. Conserv. Biol. 2018, 32, 1185-1194. [CrossRef]

33. Barry, J.; Proops, J. Seeking sustainability discourses with Q methodology. Ecol. Econ. 1999, 28, 337-345. [CrossRef]

34. Frantzi, S.; Carter, N.T.; Lovett, J.C. Exploring discourses on international environmental regime effectiveness with Q methodology: A case study of the Mediterranean Action Plan. J. Environ. Manag. 2009, 90, 177-186. [CrossRef]

35. Niedziałkowski, K.; Komar, E.; Pietrzyk-Kaszyńska, A.; Olszańska, A.; Grodzińska-Jurczak, M. Discourses on Public Participation in Protected Areas Governance: Application of Q Methodology in Poland. Ecol. Econ. 2018, 145, 401-409. [CrossRef]

36. Langston, J.D.; McIntyre, R.; Falconer, K.; Sunderland, T.; van Noordwijk, M.; Boedhihartono, A.K. Discourses mapped by Q-method show governance constraints motivate landscape approaches in Indonesia. PLoS ONE 2019, 14, e0211221. [CrossRef]

37. Weir, S.; Kerr, S. Enclosing the right to fish: A Q-study into fishers' attitudes to rights in Scottish fisheries. Ocean Coast. Manag. 2020, 187, 105116. [CrossRef]

38. Ruiz-Frau, A.; Krause, T.; Marbà, N. In the blind-spot of governance-Stakeholder perceptions on seagrasses to guide the management of an important ecosystem services provider. Sci. Total Environ. 2019, 688, 1081-1091. [CrossRef] [PubMed]

39. Curry, R.; Barry, J.; McClenaghan, A. Northern Visions? Applying Q methodology to understand stakeholder views on the environmental and resource dimensions of sustainability. J. Environ. Plan. Manag. 2013, 56, 624-649. [CrossRef]

40. Gijzel, D.; Bosch-Rekveldt, M.; Schraven, D.; Hertogh, M. Integrating Sustainability into Major Infrastructure Projects: Four Perspectives on Sustainable Tunnel Development. Sustainability 2020, 12, 6. [CrossRef]

41. Grech, A.; Chartrand-Miller, K.; Erftemeijer, P.; Fonseca, M.; McKenzie, L.; Rasheed, M.; Taylor, H.; Coles, R. A comparison of threats, vulnerabilities and management approaches in global seagrass bioregions. Environ. Res. Lett. 2012, 7, 024006. [CrossRef] 